\title{
The World's Agricultural Resources Is It Possible to Improve It Due to Heat and Drought Cases?
}

\section{C.-G. Anónimo ${ }^{1 *}$, Víctor García-Gaytán ${ }^{1 *}$, Fanny Hernández-Mendoza², Hadiseh Daneshvar3, Alan G. Yañez-Olvera ${ }^{4}$}

\author{
${ }^{1}$ Laboratorio de Análisis y Diagnóstico del Patrimonio-LADIPA, El Colegio de Michoacán, La Piedad de Cavadas, Mexico, México \\ ${ }^{2}$ Colegio de Postgraduados, Campus Montecillo, Texcoco, México \\ ${ }^{3}$ Collage of Agriculture and Natural Resource, University of Tehran, Karaj, Alborz, Iran \\ ${ }^{4}$ Laboratorio Nacional de Genómica para la Biodiversidad, Unidad de Genómica Avanzada (Langebio) Cinvestav, \\ Irapuato, México \\ Email: *vgaytan@colmich.edu.mx, *garvictan@gmail.com
}

How to cite this paper: Anónimo,C.-G. García-Gaytán, V., Hernández-Mendoza, F., Daneshvar, H. and Yañez-Olvera, A.G. (2021) The World's Agricultural Resources Is It Possible to Improve It Due to Heat and Drought Cases? Journal of Agricultural Chemistry and Environment, 10, 447-457. https://doi.org/10.4236/jacen.2021.104030

Received: October 29, 2021

Accepted: November 23, 2021

Published: November 26, 2021

Copyright $\odot 2021$ by author(s) and Scientific Research Publishing Inc. This work is licensed under the Creative Commons Attribution International License (CC BY 4.0).

http://creativecommons.org/licenses/by/4.0/

\section{Open Access}

\begin{abstract}
Competition for natural resources will affect our ability to produce food. As population grows so does food demand, which leads to enormous pressure on the supply system. Despite the threat that climate change represents, is possible to produce more food as is evidenced, for example, the worldwide increases in the average yield per year of corn, rice wheat, and soybean. However, stresses such as temperature may have a negative impact on productivity. World grain yields decrease for each degree of increase in minimum global temperature. In addition, temperature increase induces other events such as the incidence of pests and diseases and damage to germplasm. This work focuses on the perspective of food production in the world, addressed from five fundamental aspects: 2) Temperature in crop yield. 3) Stress factors cause financial losses. 4) Water use in Agriculture. 5) The urge to increase plant productivity against climate change, and finally 6) Plant diversity and conservation.
\end{abstract}

\section{Keywords}

Food, Yield, Temperature, Drought, Heat, Germplasm

\section{Introduction}

The growing competition for land, water and energy, in addition to the overexploitation of fisheries, will affect our ability to produce food, as well as the urgent 
requirement to reduce the impact of the food system on the environment [1]. An important correlate of this slowdown in population growth is the increase in wealth, and with greater purchasing power comes greater consumption and greater demand for processed foods, meat, dairy products and fish, all of which add pressure to the system of food supply [1]. If the current trend of greater agricultural intensification in richer nations and greater land clearing in developing nations continues, by 20501 billion hectares of land would be cleared worldwide [2]. Although climate change is a threat, the world can produce more food and guarantee its distribution more efficiently and equitably [3]. For example, the four main world crops, such as corn, rice, wheat and soybean, are currently experiencing improvements in average yields between 0.9 and 1.6\% per year, however, it is necessary to increase it further by 2050 . This means that the growth rate of the production of these crops is $2.4 \%$ per year [4]. The development of sedentary agricultural societies and the increase in modern agriculture are considered to have led to a decrease in the total number of plant species on which humans depend, particularly wild, semi-domesticated and cultivated vegetables [5]. Genetic resources have a great potential for genes of agri-food interest (stress resistance, biotic and abiotic genes, genes with performance qualities, genes to increase metabolites, genes to increase some trace minerals). Global environmental impact of agriculture on greenhouse gases is $24 \%$, while around 70 and $80 \%$ of fresh drinking water is used for agriculture. These last two factors must be addressed urgently on the agendas of each nation. And allocate financial resources, so that their researchers are participants in solving the problem. Bajželj et al. [6] propose that one way to achieve global food security is not to expand crops and reduce greenhouse gas emissions. According to Bodirsky et al. [7] the demand for food can be used as an indicator for food security.

Adaptation to abiotic stress is a multigenic process that involves the maintenance of homeostasis for adequate survival in an unfavorable environment [8]. Plants, because they are sessile organisms, cannot change or move their position to more suitable climate conditions, so they are affected by the effect of stress such as heat [9]. Heat stress and drought reduced cereal yields by $9 \%$ 10\% between 1964 and 2007 worldwide [10]. The reproductive stage of development in crops is more sensitive to drought or heat stress, so the number of seeds can be affected [11]. Although both stressors can occur at different times of the season, such as harvest, they can also differ between climatic periods [12]. It is suggested that these stressors can be mitigated through soil management practices, crop establishment and foliar application of growth regulators, to maintain an appropriate level of water in leaves due to osmotic adjustment and stomatal performance [13]. However, for our understanding in this manuscript it will be necessary to approach the subject from five points of view. 2) Temperature in crop yield. 3) Drought and heat as causes for great economic losses in the world. 4) Stress factors cause financial losses. 5) The urge to in- 
crease plant productivity against climate change, and finally. 6) Plant diversity and conservation.

\section{Temperature on Crop Yield}

Although, the temperature is fundamental in the growth and the yield of the crops, since they affect the processes of growth and development of the plants [14]. Generalized changes in rainfall and temperature patterns threaten agricultural production, increase the vulnerability of people who depend on agriculture for their livelihoods and may affect word food markets [15]. High temperatures can cause catastrophic loss of crop productivity and give rise to widespread famine [16]. Heat and drought are the two tensions that have a huge impact on the growth and productivity of crops. Therefore, it is necessary to understand the interventions physiological, biochemical and ecological related to these trends for greater management in crop productivity [17]. In rice cultivation it has been observed that, for each $1^{\circ} \mathrm{C}$ increase in the minimum temperature, the grain yield decreased by $10 \%$ [18]. A recent study mentions that, for each increase in degrees Celsius in the global average temperature, global yields of wheat would be reduced on average by $6.0 \%$, in rice by $3.2 \%$, in corn by $7.4 \%$, and the soybean in 3.1\% [19]. Initial studies on climate change in crops focused on the effects of the increase in the level of carbon dioxide $\left(\mathrm{CO}_{2}\right)$, global average temperature, rainfall and nutrition in agricultural production [20]. Climate change events induce other events of great agricultural importance such as the incidence of pests and diseases, and the vulnerability of germplasm [21]. Productivity growth rates will be driven mainly by technological and agronomic improvements [22]. In rice genotypes developed and exposed to a temperature of $\geq 33.7^{\circ} \mathrm{C}$ during anthesis, it caused sterility [23]. The average canopy yield due to heat stress during flowering was $0.7 \%$ when the temperature is measured at $2 \mathrm{~m}$ height [24]. The concentration of carbohydrates, starch, fructose and raffinose were lower in barley when they were grown at high temperatures [25]. The interaction of $\mathrm{CO}_{2}$ with high temperature or drought can vary according to the species $\left(\mathrm{C}_{3}\right.$ and $\left.\mathrm{C}_{4}\right)$, but it also depends on factors such as phenology, intensity and duration of stress [26].

\section{Stress Factors Cause Financial Losses}

Drought and prolonged heat pose a serious challenge since they can affect plant growth and yield, which can lead to annual losses of billions of dollars [27]. Generally, drought stress occurs when water available in the soil is reduced and atmospheric conditions cause continuous water loss through perspiration or evaporation [28]. Which leads to a reduction in leaf size, stem extension and root efficiency. Plants show a variety of physiological and biochemical responses to drought stress at the cellular level and throughout the organism, which makes it a complex phenomenon [29]. There is an urgent need for a change of focus in plant stress research, in order to understand the nature of multiple stress res- 
ponses and create pathways for plant development to obtain high high-yielding varieties resistant to multiple types of stress [30]. The response of plants to combinations of two or more stress conditions is unique and cannot be extrapolated. For example, the main climatic disasters in the US, which exceeded one billion dollars each, between 1980 and 2012, indicates that a combination of drought and heat stress caused huge millionaire losses [31]. Prolonged periods of drought cause premature death of plants, total crop loss and eventually land abandonment. Therefore, this problem will worsen in the near future in arid and semi-arid regions [32]. The strengthening of the weather forecast system, credit facilities, market linkage with better infrastructure facilities, will be key factors in obtaining the optimal price of agricultural products [33]. Therefore, it is necessary to understand these implications for agricultural crops, to develop varieties resistant to climate-induced stress [34].

\section{Water Use in Agriculture}

It is understood that crop production must increase at least twice as fast as human population growth over the next 40 years to meet world food demand [35]. Agriculture consumes $70 \%$ of fresh water worldwide. For example, approximately 1000 liters of water are required to produce $1 \mathrm{~kg}$ of cereal grain and $43,000 \mathrm{~L}^{-1}$ to produce $1 \mathrm{~kg}$ of beef. New water supplies are likely to result from conservation, recycling and improvement in the efficiency of water use [36]. The water footprint is an indicator of fresh water, the average calorie for beef is 20 times higher than for cereals and starchy roots. The water footprint per gram of protein for milk, eggs and chicken meat is 1.5 times larger than for legumes [37]. Crops with irrigation systems require a significant expenditure of fossil energy both to pump and to bring water to the crops. The delivery of 10 million liters of water from sources for $1 \mathrm{ha}^{-1}$ of corn requires an expenditure of approximately $880 \mathrm{ki}$ lowatts per hour (kWh) of fossil fuel [36]. To cope with future estimates of water scarcity, some measures aimed at streamlining and optimizing the efficiency of water consumption in the agricultural sector are critical in view of the large volumes of water needed for crop production. The correlation between the expected increase in irrigation water requirements, the critical values of renewable freshwater resources and water scarcity, indicates the need for coordination of careful regional and strategic water management policies at the national level [38]. In developed countries, water consumption for irrigation is $60 \%$ of available water resources, while in developing countries it can reach 90\% [39]. This increase in water consumption will have a negative impact on the available water in the following years. Most of the irrigation crops in the world do not have adequate management in the efficient use of water [39] [40]. The $29 \%$ of the total water footprint of the agricultural sector in the world is related to the production of animal products [37]. Investments are needed to raise the yields of food crops, to improve the management of existing irrigation systems, develop new systems, restore land and degraded water resources [41]. Finally, the future 
supply of food, including water use, will be determined by prudent management of global agricultural resources and smart investments in technology, as well as reforms carried out in institutions and policies to achieve an increase in food production. Thus, in the face of population growth and climate change, farmers should be the first objective of policies to intensify production [42] [43].

\section{It Is Necessary to Increase the Productivity of Plants Against Climate Change}

Crops against the effects of climate change and environmental stress factors such as drought, high temperatures, or salinity will require developing well-adapted plants, with improvements in their physiology and biochemistry [44]. Wild genetic resources, hereditary characteristics of plants and wild animals, are increasingly used to improve crops and domesticated livestock, as a new source of food and raw materials [45]. Crops whose wild relatives have traditionally been used as sources of useful traits continue to be more likely to include new traits of their wild relatives [46]. In addition, these wild relatives are used successfully to improve tolerance to stress conditions such as drought, heat, nutritional value, protein and calcium content [29] [47] [48] [49]. Recent research has shown that phytohormones, including auxines, cytokinins, ethylene, and gibberellins, also including brassinosteroids, jasmonates, and strigolactones can be produced by metabolically engineering abiotic stress tolerant crop plants [50]. In the case of horticulture, two of the major concerns are related to the scarcity of water for crop production and the potential for increased evapo-transpiration [51].

\section{Plant Diversity and Conservation}

Systematic effort is needed to improve the conservation and availability of crop wild relatives [52]. Unfortunately, they are a threatened resource and measures must be taken to protect them, both in their wildlife and in conservation banks [53]. Plants domestication over hundreds of years has been subject to yield and edibility mainly [54]. The lack of diversity in modern germplasm can further limit our ability to reproduce to obtain higher levels of nutrients, although the effort, has been for a few basic crops [55]. Just over 7 million accessions of plant germplasm are currently conserved in 1750 gene banks worldwide, and it is estimated that about two million accessions are unique, the conservation of these accessions is challenging and expensive. Therefore, it requires long-term secure financial resources, where the government, stakeholders and the general public intervene [56]. Agricultural practices between communities have resulted in the development of locally adapted varieties [57]. Despite the number of accessions in banks, they belong to a limited number of species. Half of them are advanced cultivars and only one third are local varieties or old cultivars [58]. These collections are required to provide an easily available source of diversity genetics for crop improvement, as well as for its introduction in other parts of the world, as well as replacement seeds for local varieties and for those lost by catastrophes 
[59]. When one speaks of the local term, it can be understood as a synonym of native, that is to say that the populations originate where they are and therefore adapt to local environmental conditions [60]. For scholars in this area, a better understanding of genetic diversity and its distribution is necessary for its future conservation and use. The above would help to conserve, where to keep the biological material, its taxonomy, the origin and evolution of the species of interest [61]. It is true that a great deal of genetic diversity is found in the small agricultural systems that are the majority of the world. These cultivation varieties are obtained through a traditional system, which is practically based on saving and exchanging local germplasm [62]. For in situ conservation it must be governed by five principles: complementarity for conservation, minimum institutional development, monitoring of an existing program, fulfillment of development objectives to increase revenues and accept new germplasms as an international mutual good [63].

\section{Conclusion}

Climate models predict that the impact and duration of periods of drought and heat stress are constantly increasing. These events have a negative impact on crops of economic interest, facing these challenges it is necessary to improve yield. Although, it is true that there are crops where yield has increased such as corn, rice, wheat and soybeans, however, is not enough to cope whit population growth. It is necessary to use technological improvements in climate monitoring, since drought or heat and/or the combination of both can cause problems in food safety. Therefore, it is necessary to provide credits to the producer and link new markets. Water shortage is present in several regions of the world, this is because agriculture consumes around $70 \%$ of fresh water globally, it will be necessary to assess the impact of water use and the need for the demand for protein foods of origin animal, such as cattle, pigs and birds. Finally, under these challenges, farmers must take care and apply water efficiently, with the aim of increasing crop productivity. Therefore, genetic improvement will be necessary for plants to resist and be well adapted to abiotic stress.

\section{Acknowledgements}

To the international consultant Dr. Víctor García for financing this manuscript, an expert in plant nutrition.

\section{Conflicts of Interest}

The authors declare no conflicts of interest regarding the publication of this paper.

\section{References}

[1] Godfray, H.C.J., Beddington, J.R., Crute, I.R., Haddad, L., Lawrence, D., Muir, J.F. and Toulmin, C. (2010) Food Security: The Challenge of Feeding 9 Billion People. 
Science, 327, 812-818. https://doi.org/10.1126/science.1185383

[2] Tilman, D., Balzer, C., Hill, J. and Befort, B.L. (2011) Global Food Demand and the Sustainable Intensification of Agriculture. Proceedings of the National Academy of Sciences of the United States of America, 108, 20260-20264.

https://doi.org/10.1073/pnas.1116437108

[3] Foley, J.A., Ramankutty, N., Brauman, K.A., Cassidy, E.S., Gerber, J.S., Johnston, M. and Balzer, C. (2011) Solutions for a Cultivated Planet. Nature, 478, 337-342. https://doi.org/10.1038/nature10452

[4] Ray, D.K., Mueller, N.D., West, P.C. and Foley, J.A. (2013) Yield Trends Are Insufficient to Double Global Crop Production by 2050. PLoS ONE, 8, Article ID: e66428. https://doi.org/10.1371/journal.pone.0066428

[5] Khoury, C.K., Bjorkman, A.D., Dempewolf, H., Ramirez-Villegas, J., Guarino, L., Jarvis, A. and Struik, P.C. (2014) Increasing Homogeneity in Global Food Supplies and the Implications for Food Security. Proceedings of the National Academy of Sciences of the United States of America, 111, 4001-4006.

https://doi.org/10.1073/pnas.1313490111

[6] Bajželj, B., Richards, K.S., Allwood, J.M., Smith, P., Dennis, J.S., Curmi, E. and Gilligan, C.A. (2014) Importance of Food-Demand Management for Climate Mitigation. Nature Climate Change, 4, 924-929. https://doi.org/10.1038/nclimate2353

[7] Bodirsky, B.L., Molinsky, S., Biewald, A., Weindl, I., Popp, A. and Lotze-Campen, H. (2015) Global Food Demand Scenarios for the 21st Century. PLoS ONE, 10, Article ID: e0139201. https://doi.org/10.1371/journal.pone.0139201

[8] Priya, M., Dhanker, O.P., Siddique, K.H. HanumanthaRao, B., Nair, R.M., Pandey, S. and Nayyar, H. (2019) Drought and Heat Stress-Related Protein: An Update about Their Functional Relevance in Imparting Stress Tolerance in Agricultural Crop. Theorical and Applied Genetics, 132, 1607-1638.

https://doi.org/10.1007/s00122-019-03331-2

[9] Nadeem, M., Li, J., Wang, M., Shah, L., Lu, S., Wang, X. and Ma, C. (2018) Unraveling Field Crops Sensitivity to Heat Stress: Mechanisms, Approaches, and Future Prospect. Agronomy, 8, Article No. 128. https://doi.org/10.3390/agronomy8070128

[10] Lesk, C., Rowhani, P. and Ramankutty, N. (2016) Influence of Extreme Weather Disaster on Global Crop Production. Nature, 529, 84-87.

https://doi.org/10.1038/nature16467

[11] Prassad, P.V.V., Staggeborg, S.A. and Ristic, Z. (2008) Impacts of Drought and/or Heat Stress on Physiological, Developmental, Growth, and Yield Processes of Crop Plant. In: Ahuja, L., Reddy, V., Saseendran, S. and Yu, Q., Eds., Response of Crops to Limited Water. Understanding and Modeling Water Stress Effects on Plant Growth Processes, Vol. 1, American Society of Agronomy, Inc., Madison, 301-355. https://doi.org/10.2134/advagricsystmodel1.c11

[12] Gobin, A. (2012) Impact of Heat and Drought Stress on Arable Crop Production in Belgium. Natural Hazards and Earth System Sciences, 12, 1911-1922. https://doi.org/10.5194/nhess-12-1911-2012

[13] Lipiec, J., Doussan, C., Nosalewicz, A. and Kondracka, L. (2013) Effect of Drought and Heat Stresses on Plant Growth and Yield: A Review. International Agrophysics, 27, 463-477. https://doi.org/10.2478/intag-2013-0017

[14] Wheeler, T.R., Craufurd, P.Q., Ellis, R.H., Porter, J.R. and Prasad, P.V. (2000) Temperature Variability and the Yield of Annual Crops. Agriculture, Ecosystems and Environment, 82, 159-167. https://doi.org/10.1016/S0167-8809(00)00224-3

[15] Lipper, L., Thornton, P., Campbell, B.M., Baedeker, T., Braimoh, A., Bwalya, M. and 
Hottle, R. (2014) Climate-Smart Agriculture for Food Security. Nature Climate Change, 4, 1068-1072. https://doi.org/10.1038/nclimate2437

[16] Bita, C. and Gerats, T. (2013) Plant Tolerance to High Temperature in a Changing Environment: Scientific Fundamentals and Production of Heat Stress-Tolerant Crops. Frontiers in Plant Science, 4, Article No. 273. https://doi.org/10.3389/fpls.2013.00273

[17] Fahad, S., Bajwa, A.A., Nazir, U., Anjum, S.A., Farooq, A., Zohaib, A., Ihsan, M.Z., et al. (2017) Crop Production under Drought and Heat Stress: Plant Responses and Management Options. Frontiers in Plant Science, 8, Article No. 1147.

https://doi.org/10.3389/fpls.2017.01147

[18] Peng, S., Huang, J., Sheehy, J.E., Laza, R.C., Visperas, R.M., Zhong, X. and Cassman, K.G. (2004) Rice Yields Decline with Higher Night Temperature from Global Warming. Proceedings of the National Academy of Sciences of the United States of America, 101, 9971-9975. https://doi.org/10.1073/pnas.0403720101

[19] Zhao, C., Liu, B., Piao, S., Wang, X., Lobell, D.B., Huang, Y. and Durand, J.L. (2017) Temperature increase reduces global yields of major crops in four independent estimates. Proceedings of the National Academy of Sciences of the United States of America, 114, 9326-9331. https://doi.org/10.1073/pnas.1701762114

[20] Porter, J.R. and Semenov, M.A. (2005) Crop Responses to Climatic Variation. Philosophical Transactions of the Royal Society B: Biological Sciences, 360, 2021-2035. https://doi.org/10.1098/rstb.2005.1752

[21] Tubiello, F.N., Soussana, J.F. and Howden, S.M. (2007) Crop and pasture response to climate change. Proceedings of the National Academy of Sciences of the United States of America, 104, 19686-19690. https://doi.org/10.1073/pnas.0701728104

[22] Lobell, D.B. and Gourdji, S.M. (2012) The Influence of Climate Change on Global Crop Productivity. Plant Physiology, 160, 1686-1697. https://doi.org/10.1104/pp.112.208298

[23] Jagadish, S.K., Craufurd, P.Q. and Wheeler, T.R. (2007) High Temperature Stress and Spikelet Fertility in Rice (Oryza sativa L.). Journal of Experimental Botany, 58, 1627-1635. https://doi.org/10.1093/jxb/erm003

[24] Siebert, S., Ewert, F., Rezaei, E.E.Kage, H. and Graß, R. (2014) Impact of Heat Stress on Crop Yield-On the Importance of Considering Canopy Temperature. Environmental Research Letter, 9, Article ID: 04412. https://doi.org/10.1088/1748-9326/9/4/044012

[25] Högy, P., Poll, C., Marhan, S., Kandeler, E. and Fangmeier, A. (2013) Impacts of temperature increase and change in precipitation pattern on crop yield and yield quality of barley. Food Chemistry, 136, 1470-1477. https://doi.org/10.1016/j.foodchem.2012.09.056

[26] Kadam, N.N., Xiao, G., Melgar, R.J., Bahuguna, R.N., Quinones, C., Tamilselvan, A. and Jagadish, K.S. (2014) Agronomic and Physiological Responses to High Temperature, Drought, and Elevated $\mathrm{CO}_{2}$ Interactions in Cereals. Advances in agronomy, 127, 111-156. https://doi.org/10.1016/B978-0-12-800131-8.00003-0

[27] Mittler, R. and Blumwald, E. (2010) Genetic Engineering for Modern Agriculture: Challenges and Perspectives. Annual Review of Plant Biology, 61, 443-462. https://doi.org/10.1146/annurev-arplant-042809-112116

[28] Jaleel, C.A., Manivannan, P., Wahid, A., Farooq, M., Al-Juburi, H.J., Somasundaram, R. and Panneerselvam, R. (2009) Drought Stress in Plants: A Review on Morphological Characteristics and Pigments Composition. International Journal of Agriculture and Biology, 11, 100-105. 
[29] Farooq, S. and Azam, F. (2001) Co-Existence of Salt and Drought Tolerance in Triticeae. Hereditas, 135, 205-210. https://doi.org/10.1111/j.1601-5223.2001.00205.x

[30] Atkinson, N.J. and Urwin, P.E. (2012) The Interaction of Plant Biotic and Abiotic Stresses: From Genes to the Field. Journal of Experimental Botany, 63, 3523-3543. https://doi.org/10.1093/jxb/ers100

[31] Suzuki, N., Rivero, R.M., Shulaev, V., Blumwald, E. and Mittler, R. (2014) Abiotic and Biotic Stress Combinations. New Phytologist, 203, 32-43. https://doi.org/10.1111/nph.12797

[32] Fita, A., Rodríguez-Burruezo, A., Boscaiu, M., Prohens, J. and Vicente, O. (2015) Breeding and Domesticating Crops Adapted to Drought and Salinity: A New Paradigm for Increasing Food Production. Frontiers in Plant Science, 6, Article No. 978. https://doi.org/10.3389/fpls.2015.00978

[33] Singh, R.P. and Reddy, K.R. (2013) Impact of Climate Change and Farm Management. Climate Change and Environmental Sustainability, 1, 53-72. https://doi.org/10.5958/j.2320-6411.1.1.006

[34] Hatfield, J.L., Boote, K.J., Kimball, B.A., Ziska, L.H., Izaurralde, R.C., Ort, D. and Wolfe, D. (2011) Climate Impacts on Agriculture: Implications for Crop Production. Agronomy Journal, 103, 351-370. https://doi.org/10.2134/agronj2010.0303

[35] Sposito, G. (2013) Green Water and Global Food Security. Vadose Zone Journal, 12, 1-6. https://doi.org/10.2136/vzj2013.02.0041

[36] Pimentel, D., Berger, B., Filiberto, D., Newton, M., Wolfe, B., Karabinakis, E. and Nandagopal, S. (2004) Water Resources: Agricultural and Environmental Issues. BioScience, 54, 909-918. https://doi.org/10.1641/0006-3568(2004)054[0909:WRAAEI]2.0.CO;2

[37] Mekonnen, M.M. and Hoekstra, A.Y. (2012) A global Assessment of the Water Footprint of Farm Animal Products. Ecosystems, 15, 401-415. https://doi.org/10.1007/s10021-011-9517-8

[38] Mancosu, N., Snyder, R., Kyriakakis, G. and Spano, D. (2015) Water Scarcity and Future Challenges for Food Production. Water, 7, 975-992. https://doi.org/10.3390/w7030975

[39] Velasco-Muñoz, J., Aznar-Sánchez, J., Belmonte-Ureña, L. and Román-Sánchez, I. (2018) Sustainable Water Use in Agriculture: A Review of Worldwide Research. Sustainability, 10, Article No. 1084. https://doi.org/10.3390/su10041084

[40] Van Huis, A., Van Itterbeeck, J., Klunder, H., Mertens, E., Halloran, A., Muir, G. and Vantomme, P. (2013) Edible Insects: Future Prospects for Food and Feed Security (No. 171). Food and Agriculture Organization of the United Nations, Rome.

[41] Khan, S. and Hanjra, M.A. (2009) Footprints of Water and Energy Inputs in Food Production-Global Perspectives. Food Policy, 34, 130-140.

https://doi.org/10.1016/j.foodpol.2008.09.001

[42] Hanjra, M.A. and Qureshi, M.E. (2010) Global Water Crisis and Future Food Security in an Era of Climate Change. Food Policy, 35, 365-377.

https://doi.org/10.1016/j.foodpol.2010.05.006

[43] Herrero, M., Thornton, P.K., Notenbaert, A.M., Wood, S., Msangi, S., Freeman, H.A., Lynam, J., et al. (2010) Smart Investments in Sustainable Food Production: Revisiting Mixed Crop-Livestock Systems. Science, 327, 822-825. https://doi.org/10.1126/science.1183725

[44] Ahuja, I., de Vos, R.C., Bones, A.M. and Hall, R.D. (2010) Plant Molecular Stress Responses Face Climate Change. Trends in Plant Science, 15, 664-674. 
https://doi.org/10.1016/j.tplants.2010.08.002

[45] Prescott-Allen, R. and Prescott-Allen, C. (2013) Genes from the Wild: Using Wild Genetic Resources for Food and Raw Materials. Routledge, London.

https://doi.org/10.4324/9781315066769

[46] Hajjar, R. and Hodgkin, T. (2017) The Use of Wild Relatives in Crop Improvement: A Survey of Developments over the Last 20 Years. Euphytica, 156, 1-13. https://doi.org/10.1007/s10681-007-9363-0

[47] Sheehy, J., Elmido, A., Centeno, G. and Pablico, P. (2005) Searching for New Plants for Climate Change. Journal of Agricultural Meteorology, 60, 463-468. https://doi.org/10.2480/agrmet.463

[48] Kovacs, M.I.P., Howes, N.K., Clarke, J.M. and Leisle, D. (1998) Quality Characteristics of Durum Wheat Lines Deriving High Protein from a Triticum dicoccoides (6b) Substitution. Journal of Cereal Science, 27, 47-51. https://doi.org/10.1006/jcrs.1997.0144

[49] Bamberg, J.B. and Hanneman, R.E. (2013) Calcium Rich Potatoes: It's in Their Genes. Agricultural Research Magazine, 51, 18-20.

[50] Wani, S.H., Kumar, V., Shriram, V. and Sah, S.K. (2016) Phytohormones and Their Metabolic Engineering for Abiotic Stress Tolerance in Crop Plants. The Crop Journal, 4, 162-176. https://doi.org/10.1016/j.cj.2016.01.010

[51] Snyder, R.L. (2017) Climate Change Impacts on Water Use in Horticulture. Horticulture, 3, Article No. 27. https://doi.org/10.3390/horticulturae3020027

[52] Castañeda-Álvarez, N.P., Khoury, C.K., Achicanoy, H.A., Bernau, V., Dempewolf, H., Eastwood, R.J., Müller, J.V., et al. (2016) Global conservation Priorities for Crop Wild Relatives. Nature Plants, 2, Article No. 16022. https://doi.org/10.1038/nplants.2016.22

[53] Dempewolf, H., Baute, G., Anderson, J., Kilian, B., Smith, C. and Guarino, L. (2017) Past and Future Use of Wild Relatives in Crop Breeding. Crop Science, 57, 1070-1082. https://doi.org/10.2135/cropsci2016.10.0885

[54] Mammadov, J., Buyyarapu, R., Guttikonda, S.K., Parliament, K., Abdurakhmonov, I. and Kumpatla, S.P. (2018) Wild Relatives of Maize, Rice, Cotton, and Soybean: Treasure Troves for Tolerance to Biotic and Abiotic Stresses. Frontiers in Plant Science, 9, Article No. 886. https://doi.org/10.3389/fpls.2018.00886

[55] Smýkal, P., Nelson, M., Berger, J. and von Wettberg, E. (2018) The Impact of Genetic Changes During crop Domestication. Agronomy, 8, Article No. 119. https://doi.org/10.3390/agronomy8070119

[56] Fu, Y.B. (2017) The Vulnerability of Plant Genetic Resources Conserved ex Situ. Crop Science, 57, 2314-2328. https://doi.org/10.2135/cropsci2017.01.0014

[57] De Carvalho, M.A.P., Bebeli, P.J., Bettencourt, E., Costa, G., Dias, S., Dos Santos, T.M. and Slaski, J.J. (2013) Cereal Landraces Genetic Resources in Worldwide Gene Banks. A Review. Agronomy Sustainable Development, 33, 177-203. https://doi.org/10.1007/s13593-012-0090-0

[58] Hammer, K., Arrowsmith, N. and Gladis, T. (2003) Agrobiodiversity with Emphasis on Plant Genetic Resources. Naturwissenschaften, 90, 241-250. https://doi.org/10.1007/s00114-003-0433-4

[59] Schoen, D.J. and Brown, A.H. (2001) The Conservation of Wild Plant Species in Seed Banks: Attention to Both Taxonomic Coverage and Population Biology Will Improve the Role of Seed Banks as Conservation Tools. BioScience, 51, 960-966. https://doi.org/10.1641/0006-3568(2001)051[0960:TCOWPS]2.0.CO;2 
[60] Vander Mijnsbrugge, K., Bischoff, A. and Smith, B. (2010) A Question of Origin: Where and How to Collect Seed for Ecological Restoration. Basic and Applied Ecology, 11, 300-311. https://doi.org/10.1016/j.baae.2009.09.002

[61] Rao, V.R. and Hodgkin, T. (2002) Genetic Diversity and Conservation and Utilization of Plant Genetic Resources. Plant Cell, Tissue and Organ Culture, 68, 1-19. https://doi.org/10.1023/A:1013359015812

[62] Van Heerwaarden, J., Van Eeuwijk, F.A. and Ross-Ibarra, J. (2010) Genetic Diversity in a Crop Metapopulation. Heredity, 104, 28-39. https://doi.org/10.1038/hdy.2009.110

[63] Brush, S.B. (1991) A Farmer-Based Approach to Conserving Crop Germplasm. Economic Botany, 45, 153-165. https://doi.org/10.1007/BF02862044 